\title{
Correction: Stratigraphic and structural controls on groundwater salinity variations in the Poso Creek Oil Field, Kern County, California, USA
}

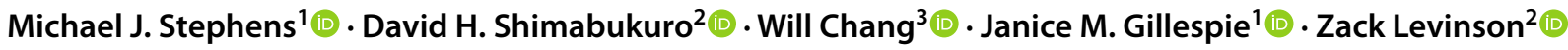

Published online: 8 January 2022

This is a U.S. government work and not under copyright protection in the U.S.; foreign copyright protection may apply 2022

Correction: Hydrogeology Journal (2021) 29:2803-2820 https://doi.org/10.1007/s10040-021-02381-5

Figure S4 in the electronic supplementary material (ESM) has been replaced to display the correct contours.

The original article has been corrected.

Supplementary Information The online version contains supplementary material available at https://doi.org/10.1007/s10040-021-02443-8.

Open Access This article is licensed under a Creative Commons Attribution 4.0 International License, which permits use, sharing, adaptation, distribution and reproduction in any medium or format, as long as you give appropriate credit to the original author(s) and the source, provide a link to the Creative Commons licence, and indicate if changes were made. The images or other third party material in this article are included in the article's Creative Commons licence, unless indicated otherwise in a credit line to the material. If material is not included in the article's Creative Commons licence and your intended use is not permitted by statutory regulation or exceeds the permitted use, you will need to obtain permission directly from the copyright holder. To view a copy of this licence, visit http://creativecommons.org/licenses/by/4.0/.

Publisher's Note Springer Nature remains neutral with regard to jurisdictional claims in published maps and institutional affiliations.
The original article can be found online at https://doi.org/10.1007/ s10040-021-02381-5.

Michael J. Stephens

mjstephens@usgs.gov

1 US Geological Survey, California Water Science Center, 6000 J Street, Sacramento, CA 95819, USA

2 Department of Geology, California State University, $6000 \mathrm{~J}$ Street, CA 95819 Sacramento, USA

3 Hypergradient LLC, Berkeley, CA 94703, USA 